\title{
MORFOLOGIA DO VERBO TUPI
}

\author{
Arion Dall'Igna Rodrigues \\ Instituto de Pesquisas da Universidade do Paraná
}

0. Introdução.

1. O verbo: generalidades.

2. Primeira conjugação.

3. Segunda conjugação.

4. Vozes.

5. Aspectos.

6. Modos.

7. Nomes deverbativos.

8. Verbos ditemáticos.

9. Negação.

0.1. Generalidades. O presente artigo constitui um ensaio de sistematização da morfologia do verbo em Tupi antigo. A expressão Tupi antigo é aqui empregada para designar a língua falada pelos índios Tupinambá do Brasil oriental no período abrangido pelos séculos XVI e XVII. As fontes para o conhecimento desta língua estão especificadas em outro artigo do autor '; por isso aqui se faz referência apenas às que mais diretamente forneceram material para êste trabalho: são as gramáticas de Anchieta e Figueira ${ }^{2}$ e, subsidiàriamente, o "Vocabulário na língua brasílica" 3; os textos contribuiram pa-

1 Rodrigues, Arion Dall'Igna, Esbôço de uma introduçāo ao estudo da língua Tupi. Logos (Curitiba), n. 13 (1951), pp. 53-54.

2 Anchieta, Joseph de, Arte de gramática da língua mais usada na Costa do Brasil, feita pelo p. ... Ed. da Bibl. Nac. do Rio de Janeiro Rio, 1953. (E idêntica a ediçăo da Edítôra Anchieta, S. Paulo, 1946).

Figueira, Luis, Arte de grammatica da lingua brasilica do padre.... Nova edição dada à luz e anotada por Emilo Allain. Rio de Janelro, 1880 .

3 Vocabulário na língua braślica. Manuscrito português-tupi do séc. XVII, coordenado e prefaciado por Plínio Ayrosa. Col. do Dep. de Cultura, vol. XX. S. Paulo, 1938. 
ra esclarecer, confirmar ou completar o material contido nas gramáticas e no vocabulário. Alguns aspectos da morfologia verbal já foram apresentados em artigo anterior ${ }^{4}$.

O tratamento do sistema verbal do Tupi antigo aqui apresentado não pretende ser exaustivo e, muito menos, definitivo. Há lacunas que ficam a solicitar novos estudos e há pontos controvertíveis cuja fixação definitiva dependerá, igualmente, de investigaçōes ulteriores (particularmente os parágrafos respeitantes aos aspectos verbais são apresentados com não pequena reserval. A análise lingüistica por meio da qual se deduziu o sistema é o que talvez se poderia chamar uma análise "tradicional", no sentido de que se prende, em suas linhas gerais, a uma tradição gramatical européia, vigente em nossas escolas, e que se distingue das novas técnicas de análise estrutural desenvolvidas pela lingüística norte-americana ou pela glossemática de Hjelmslev. A vantagem que pode apresentar esta análise "tradicional" é a de ser a mais acessível aos leitores brasileiros, dos quais as novas técnicas são ainda pouco conhecidas.

0.2. Fonemas. Os fonemas do Tupi antigo são os seguintes: a) consoantes $\mathbf{p} \mathbf{t} \mathbf{k}$ (oclusivas surdas não nasalizadas), mb nd $\mathbf{n g}$ (oclusivas sonoras nasalizadas), $m \mathbf{n} \tilde{\mathbf{n}}$ (oclusivas sonoras nasais), b (em posição final, oclusiva; em posição inicial e medial, fricativa sonora bilabial), $\mathbf{s} \mathbf{x}$ (fricativas surdas, dental e palatal resp.) $\mathbf{r}$ (vibrante apical); b) semivogais $\hat{\mathbf{i}} \hat{\mathbf{u}}$; c) vogais orais i e a o u y (esta última, alta posterior, não-arredondada), vogais nasais $\tilde{\mathbf{i}} \overline{\mathbf{e}} \tilde{\mathbf{a}} \tilde{\mathbf{o}} \overline{\mathbf{u}} \overline{\mathbf{y}}$; são nasalizadas as vogais precedidas ou seguidas por consoante nasal ou precedidas por vogal nasal. A semivogal û, quando inicial ou intervocálica, apresenta-se em geral consonantizada, como oclusiva lábiovelar sonora; esta variante é aqui escrita gû ${ }^{5}$.

0.3. Fenômenos fonéticos. São indicados aqui, sumàriamente, os fenômenos fonéticos que mais interessam à morfologia verbal:

4 Rodrigues, Arion Dall'Igna, Análise morfológica de um texto tupi. Logos (Curitiba), n. 15 (1952), pp. 56-77.

isegundo a fonêmica norte-americana trata-se de um só fonema, razão por que deveria ser representado de uma só maneira. 
a) p t $\mathbf{k}$ quando precedidos por vogal nasal ou nasalizada mudam-se em mb nd ng; nas mesmas condições $s$ muda-se em nd, $\mathbf{r}$ em $n$.

b) $\mathbf{r}$ pode mudar-se em $\mathbf{n}$ quando, à sílaba em que êle figura, segue-se sílaba com vogal nasal ou nasalizada; nas mesmas condições, î pode mudar-se em $\tilde{\mathbf{n}}$.

c) b em sílaba átona muda-se em $\mathbf{m}$ quando precedido por vogal nasal ou nasalizada.

d) $s$ muda-se em $\mathbf{x}$ quando precedido por $\mathbf{i}$ ou $\hat{1}$.

e) $\mathbf{e}+\mathbf{e}>\mathbf{e}$.

f) $\mathbf{m b}$ nd alternam com $\mathbf{m} \mathbf{n}$.

0.4.1. Categorias de temas. Segundo o conceito que exprimem, distinguem-se três categorias de temas: 1) temas de substantivos - os que designam um sêr, 2) temas de adjetivos - os que exprimem uma qualidade, 3) temas verbais - os que denotam um processo (ação, estado, mudança de estado).

0.4.2. Os temas podem sẹr vocálicos ou consonânticos. Vocálicos são os que terminam em vogal; consonânticos são os que terminam em consoante ou em semivogal. As consoantes que ocorrem no final dos temas são b $\mathbf{k} \mathbf{n g} \mathbf{m} \mathbf{n}$ r. Todos os temas são oxítonos.

0.4.3. Classes de temas. Há duas classes de temas:

I - temas que não recebem prefixo de relação,

II - temas que recebem prefixo de relação.

A classe I pertencem todos os temas começados por consoante ou semivogal e parte dos temas começados por vogal; à classe II pertencem só temas começados por vogal.

0.4.4 Aspectos temáticos. Todos os temas podem apresentar-se em dois aspectos: nominal e verbal. No aspecto nominal significam:

os temas de substantivos - os nomes dos sêres,

os temas de adjetivos — os nomes das qualidades ou sêres que possuem essas qualidades, ação).

os temas verbais - os nomes dos processos (nomes de 
No aspecto verbal significam:

os temas de substantivos - ter o sêr nomeado,

os temas de adjetivos - ter a qualidade ou ser da qualidade designada, .

os temas verbais - o desenrolar do processo indicado.

Os temas vocálicos ficam invariáveis em ambos os aspectos, não apresentando distinção morfológica; p. ex.: t. kó I "roça", asp. nom. kó "a roça", asp. verb. kó "ter roça". Os temas consonâníicos, porém, formam o aspecto nominal com o sufixo -a, enquanto ficam invariáveis $n_{0}$ aspecto verbal; $p$. ex.: $t$. úb II "pai", asp. nom. úb-a "o pai", asp. verb. úb "ter pai".

0.4.5. Prefixo de relação. Os temas da classe II recebem o prefixo r-, quando sāo imediatamente precedidos por um substantivo (salvo em caso de composição) ou pelos pronomes das 1a. e 2a. pessoas, da 1a. classe (0.5.1.); p. ex.: kunumí r-úb-a "o pai do menino", xe-r-úb "eu tenho pai".

0.5.0. Pronomes. Indicam-se a seguir os pronomes pessoais que concorrem nas formas verbais, omitidos quaisquer detalhes que não interessem a êste ensaio. As pessoas são as seguintes: 1a. s. (eu), 1a. p. excl. (nós outros, com exclusão da pessoa a quem se fala, éu e êle ou êles); 1a. p. incl. (nós, eu e tu ou vós, ou eu e tu ou vós e êle ou êles); 2a. s. (tu), 2a. p. (vós), 3a. c. refl. (êle mesmo, ela mesma, êles mesmos, elas mesmas); 3a. c. irrefl. (êle, ela, êles, elas).

0.5.1. Primeira classe: 1a. s. xe, ixé, 1a. p. excl. oré, 1.a p. incl. îandé, 2a. s. nde, endé, 2a. p. pe, peē, 3a. c. refl. o, $3 a$. c. irrefl. i, s-, (t-). Os pronomes desta classe desempenham três funçōes: subjetiva (sujeito), objetiva (objeto direto) e relativa

6 Abreviaturas usadas: abs. forma absuluta, aç. açāo, adj. adjetivo, ag. agente, asp. aspecto, c. comum (singular e plural), caus. causativo, c.-com. causativo-comitativo, c.-prep. causativo-prepasitivo, cf. conferir, circ. circunstáncia, conj. conjugação, excl. exclusivo, freq. freqüentativo, fut. futuro, ger. gerúndio, hab. habitual, imp. imperativo, incl. inclusivo, ind. indicativo,int. intensivo, intr. intransitivo, irreal. irrealizado, irrefl. irreflexivo, nāo reflexivo, lit. literalmente, n. nome, neg. negaçāo, forma negativa, nom. nominal, obj. objeto, p., pl. plural, p. ex. por exemplo, pac. paciente, perm permissivo, pret. pretérito, rec. reciproco, refl. reflexivo, rel. relativo, s. singular, snbj. subjuntivo, subst. substantivo, t. ... I tema da classe I, t. ... II tema da classe II, tr. transitivo, verb. verbal, 1a. s. 1a. pessoa do singular, 2a. p. 2a. pessoa do plural, etc. 
(objeto indireto e possessivo ou genitivo). Mas ixé, endé, pee só se empregam subjetivamente, como formas independentes.

0.5.2. Segunda classe: 1a. s. a, 1a. p. excl. oró, 1a. p. incl. îa, 2a. s. ere, 2a. p.pe, 3a. c. o. Estes pronomes só desempenham a função subjetiva e são usados exclusivamente na conjugação do indicativo I e do permissivo dos temas verbais (2.1.1. e 2.2.1).

0.5.3. Terceira classe: 1a. s. gûi, 1a. p. excl. oro, 1a. p. incl. îa, 2a. s. e, 2a. p. pe, 3a. c.o. Os pronomes da 3a. classe também só desempenham a função subjetiva, e têm seu uso limitado ao gerúndio dos verbos intransitivos da 1a. conjugação (2.4.1), salvo as formas da $2 a$. s. e da $2 a$. p., que se empregam também no imperativo da 1a. conjugação (2.3.1).

0.5.4. Quarta classe: 1a.s. e p. $\longrightarrow$ 2a. s. oro "eu, nós... te", 1a. s. e p. $\rightarrow$ 2a. p. opo "eu, nós... vos". Estes pronomes exercem simultâneamente as funções de sujeito e de objeto. Sôbre seu uso v. 2.5.2.

0.5.5. Quinta classe: 2a. s. îepé, 2a. p. pê̂epé. V. 2.5.3.

\section{O VERBO: GENERALIDADES}

1.1. Conjugações. A conjugação de um verbo consiste na união do tema aos pronomes pessoais que representam o sujeito e o objeto direto do processo verbal. Distinguimos duas conjugações:

1a. conjugação, compreendendo os temas pròpriamente verbais, que se conjugam com os pronomes da 2a. classe (0.5.2);

2a. conjugação, compreendendo os temas nominais (substantivos e adjetivos no aspecto verbal), que só se conjugam com os pronomes da 1a. classe (0.5.1).

1.2. Classificação dos verbos. Quanto à sua significação, os verbos classificam-se em:

a) intransitivos - os que têm significação completa e não admitem objeto direto;

b) transitivos - os que têm significação incompleta e, por isso, não podem ocorrer sem um objeto direto necessário. 
1.3.1. Classificação das formas verbais. Classificam-se em dois grupos as formas do verbo:

a) formas remáticas (pròpriamente verbais): indicativo I ou remático, permissivo, imperativo, gerúndio e nome relativo;

b) formas onomáticas (de natureza nominal): indicativo II ou onomático, subjuntivo e nomes de ação, de agente, de circunstância, de objeto, de paciente, de agente habitual, de propensão.

1.3.2. As formas remáticas conjugam-se com os pronomes da 2a., da 3a., da 4a. e da 5a. classes; as formas onomáticas com os pronomes da 1a. classe, tal como os adjetivos e substantivos.

1.4. Significação das formas verbais:

a) formas remáticas:

indicativo I - exprime a simples realização do processo verbal; p. ex.: a-s-epiák yár-a "vi uma canoa", a-só "eu fui";

permissivo - exprime autorização (t-ere-só "vás, podes ir"), pedido de licença (t-a-só "seja-me permitido ir"), ordem, exortaçāo (t-îa-só "vamos!"); "vai!";

imperativo - exprime ordem ou pedido; p. ex.: e-só

gerúndio - exprime: a) um processo realizado simultâneamente com outro processo (gerúndio contemporâneo, p. ex.: a-ñeéng gûi-xó-bo "vou falando, i. é, falo e vou simultâneamente"); b) a finalidade ou propósito do processo indicado por outro verbo (gerúndio final, p. ex.: a-só gûi-ñeéng-a "eu vou para falar"); c) um processo realizado pelo mesmo sujeito que já realizou outro processo, mas sem simultaneidade (gerúndio aditivo, p. ex.: xe-aîubán, xe-mo-mbytá-bo, kûár-a pukú-î o-kag $\hat{u}$-ábo, o-poraséî-a, o-îegûák-a "abraçaram-me e fizeramme ficar, e durante todo o dia beberam cauim, dançaram e enfeitaram-se");

b) formas onomáticas:

indicativo II - exprime a realização do processo verbal quando subordinada a uma circunstância expressa; p. ex.: kûesé xe-só-û "fui ontem"; 
subjuntivo - exprime -um processo que é causa ou condição de outro processo; p. ex.: xe-mondó-reme a-só "fui porque me mandaram" ou "fui quando me mandaram"; xe-mondó-reme-mo a-só-mo "se me mandassem, eu iria".

Para os nomes deverbativos, v. seção 7.

\section{PRIMEIRA CONJUGAÇÃO}

\section{Indicativo I}

2.1.1. Verbos intransitivos. Nos verbos intransitivos, forma-se o indicativo I pela prefixação do pronome pessoal sujeito (2.a classe) ao tema verbal; p. ex.: t. só I intr. "ir", 1a. s. a-só, 1a. p. excl. oro-só, 1a. p. incl. îa-só, 2a. s. ere-só, 2a. p. pe-só, 3a. c. o-só "eu fui, tu foste, etc."

2.1.2. Verbos transitivos. Nos verbos transitivos, sempre há-de-ser expresso o objeto. Se êste fôr da 3.a pessoa irreflexiva poderá ser expresso nominalmente ou representado pelo pronome respectivo; neste último caso, o pronome objeto (1a. classe) fica intercalado entre o pronome sujeito (2.a classe) e o tema; p. ex.: t. nupã I tr. "açoitar", 1.a s. a-î-nupã "eu o açoitei"; t. epîák II tr. "ver", 1.a. s. a-s-epiáák "eu o vi".

Os temas da classe I começados por s- mudam s- em x- após o pronome i (0.3.d): t. suú I. tr. "morder", 1.a s. a-î-xuú "eu o (os) mordi"; nos começados por $\hat{\imath}$, o pronome i funde-se com essa semivogal: t. îuká I tr. "matar", 1a. s. a-îuká "eu o (os) matei“" (por *a-î-1̂uká).

O pronome i que, intercalado junto aos demais temas da classe I, muda-se em $\hat{\imath}$, transforma-se em $\tilde{\mathbf{n}}$ quando o tema começa por vogal nasal ou nasalizada (cf. 0.3.b); t. amĩ I tr. "expremer", 1.a s. a-ñ-amĩ "eu o expremi".

2.1.2.1. Nos temas monossilábicos da classe I, em lugar do pronome objeto $i$, intercala-se entre o sujeito e o tema o prefixo îo-; nos temas monossilábicos da classe II, êste prefixo é intercalado entre o sujeito e o pronome objeto s-; na 3.a pessoa, porém muito freqüentemente omite-se o prefixo îo-. $P$. ex.: t. súb I tr. "visitar", 1a. s. a-îo-súb "eu o (os) visitei", 3a. c. o-îo-súb ou o-súb "êle o (os) visitou, êles visitaram-no (-nos)"; 
t. én II tr. "derramar", 1a. s. a-ño-s-én (cf. 0.3.b) "eu o derramei", 3a. c. o-ño-s-én "derramou-o, derramaram-no".

2.1.2.2. Quando o objeto vem expresso nominalmente, pode ser ou intercalado entre o pronome sujeito e o tema verbal, ou colocado à parte do verbo (antes ou depois), caso, êste último, em que se intercala o pronome objeto; p. ex.: a-kunumi-nupã ou kunumí a-î-nupã ou a-î-nupã kunumí "eu surrei o menino"

O substantivo intercalado forma um composto com o tema verbal ${ }^{7}$ e pode ser empregado na forma absoluta ${ }^{8}$ ou na 3.a c. irrefl. Emprega-se esta última forma quando é mencionado o nome do possuidor do objeto, o qual nome é posposto ao verbo. P. ex.: t. esá II "ôlho" + t. kutúk I tr. "ferir" $=$ esá-kutúk "ferir olhos": a) construção com a forma absolutà - a-t-esá-kutúk "eu feri olhos (humanos)", b) construção com a forma da 3.a c. irrefl. — a-s-esá-kutúk aîurú "eu feri os olhos do papagaio"; t. pó I "mão" + t. kutúk I tr. "ferir" $=$ pókutúk "ferir mãos": a) construção com a forma absoluta a-mbó-kutúk "eu feri mãos (humanas)", b) construção com a forma da 3.a c. irrefl. - a-î-pó-kutúk xe-r-úb-a "eu feri as mãos de meu pai".

2.1.2.3. Os temas causativo-comitativos (4.2.1-3), que pertencem à classe II, apresentam as seguintes particularidades:

a) não se thes afixa o pronome objeto: $t$. era-só II "levar", 1a. p. excl. oro-era-só "nós outros o levamos", 3a. c. o-era-só o-sy "êle levou sua mãe";

b) o tema perde a vogal inicial e- na 1.a s., 1.a p. incl., 2.a s. e 2.a p., isto é, sempre que o pronome não termina em -o:

7 Cf. Arion Dall'Igna Rodrigues, A composiçāo em Tupi. Logos (Curitiba), n. 14 (1951), pp. 63-70; p. 70 (8 da separata).

8 "Os temas, que designam sêres passíveis de relacionar-se a homens, possuem, no aspecto nominal, uma forma absoluta, a qual indica essa relaçāo com sêres humanos"; "nos temas da classe II, a forma absoluta. é caracterizada pelo prefixo $t$-; em alguns, porém, forma-se pela perda da vogal inicial e noutros é indistinta"; "nos temas da classe I iniciados por p, é caracterizada a forma absoluta pela nasalizaçăo do p, que se muda em mb ou m; nos cemais temas desta classe é indistinta". Arion Dall'Igna Rodrigues, o. c., p. 66 (p. 4 da separata). 
t. era-só II "levar", 1.a s. a-ra-só, 1.a p. incl. îa-ra-só, 2.a s. ere-ra-só, 2.a p. pe-ra-só;

c) freqüentemente desenvolve-se o fonema -g $\hat{u}$ - entre os pronomes que terminam em -o e o tema: 1.a p. incl. oro-era-só ou oro-gĥu-era-só, 3.a c. o-era-só ou o-gûu-era-só.

2.1.2.4. Com os temas causativos (4.1.), que pertencem à classe I, pode-se dispensar o pronome objeto (especialmente nos dialetos meridionais): t. mo-ín I "pôr", 1.a s. a-î-mo-ín ou a-mo-ín "eu o pus".

\section{Permissivo}

2.2. O permissivo forma-se do indicativo I, antepondo-se o prefixo ta- (diante de consoante) ou t- (diante de vogal ou semivogal) aos pronomes sujeitos: $t$, só I intr. "ir", 2.a p. tape-só "podeis ir, ide", $3 . a$ c. t-o-só "que êle vá, que êles vão", 1a. p. incl. t-îa-só "vamo-nos!" 2a. s. t-ere-só "podes ir".

t-îa- (1.a p. incl.) pode pronunciar-se xîa-: xîa-ñeéng "falemos" (t. ñeéng I intr. "falar"). Em vez de $t$-îa- também ocorre t-i- ou i-: t-1̂a-r-úr ou t-i-rúr- ou i-r-úr "tragamos" (t. er-úr II c.- com. "trazer").

\section{Imperativo}

2.3. O imperativo da 1a. conjugação forma-se com os pronomes da $2 a$. pessoa da $3 a$. classe (0.5.3). A êle se aplica tudo o que foi dito do indicativo I em 2.1.2. Exs.: t. ñeéng I intr. "falar", 2.a s. e-ñeéng "fala", 2.a p. pe-ñeéng "falai"; t.

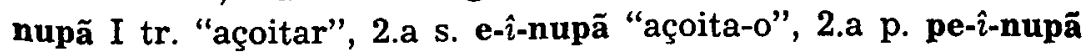
"açoitai-o"; t. epîák II tr. "ver", 2.a s. e-s-epîák "vê-o", $2 . a$ p. pe-s-epiák "vêde-o"; t. súb I tr. "visitar", 2.a s. e-îo-súb "vi-

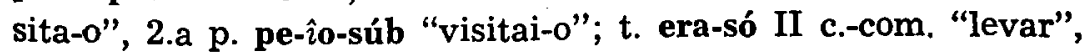
2.a s. e-ra-só "leva-o", 2.a p. pe-ra-só "levai-o".

\section{Gerúndio}

2.4.1. Verbos intransitivos. O gerúndio dos verbos intransitivos da 1.a conjugação forma-se $c^{`} m$ a prefixação, ao tema, dos pronomes sujeitos da 3.a classe (0.5.3.): t. puká I intr. "rir", 1.a s. gûi-puká-bo, 1.a p. excl. oro-puká-bo, 1.a p. incl. îa-puká-bo, 2.a s. e-puká-bo, 2.a p. pe-puká-bo, 3.a c. o- 
puká-bo "para (eu) rir", "rindo (eu), etc. t. só I intr. "ir", 1a. s.gûi-xó-bo, 1.a p. excl. oro-só-bo, etc.

2.4.2. Verbos transitivos. $O$ gerúndio dos verbos transitivos forma-se apenas com a anteposiçāo, ao tema, do objeto direto, pronome (1.a classe) ou substantivo, e sem expressão do sujeito, o qual é sempre o mesmo do verbo a que o gerúndio acompanha: o-úr i-kuáp-a "veio para conhecê-lo" (t. kuáb I tr. "conhecer"), o-úr s-epiák-a "veio para vê-lo" (t. epiáa II tr. "ver"); o-úr kunumí kuáp-a "veio para conhecer o menino"” o-úr kunumí r-epíák-a "veio para ver o menino".

2.4.3. Terminação do gerúndio. A terminação do gerúndio constitui-se da seguinte maneira:

a) os temas terminados em -r perdem essa consoante: $t$. potár I tr. "querer”, ger. potá;

b) os temas terminados em outras consoantes e em semivogal recebem o sufixo a: t. moñáng I tr. "fazer", ger. moñáng-a; t. epiák II tr. "ver", ger. epiák-a; t. mondú̂̂ I caus. "fazer transbordar", ger. mo-ndúîa; t. mo-ngaráû I caus. "luxar", ger.mo-ngará $\hat{u}$-a;

c) os temas terminados em -b, porém, mudam esta consoante em -p diante do sufixo -a: t. mo-ndéb I caus. "pôr", ger. mo-ndép-a; t. aûsúb II tr. "amar, ger. aûsúp-a;

d) os temas terminados em vogal recebem o sufixo -abo; na junção dêste ao tema, porém, verificam-se as seguintes particularidades fonéticas, deccrrentes do encontro da vogai final do tema com a vogal inicial do sufixo:

-á + abo > -ábo: t. iuká I tr. "matar", ger. îuká-bo;

-é + abo > -ébo: t. eé II tr. "ralar", ger. eé-bo;

-ó. + abo > -óbo: t. ó I tr. "tapar”, ger. ó-bo;

-i + abo > íábo: t. apití I tr."matar", ger, apitî-ábo;

-ú + abo > ûábo: t. peîú I. tr. "soprar", ger. peîûábo;

-y + abo > -ýábo: t. aby I tr. "errar", ger. abŷ-ábo;

e) se -ú não fôr precedido por consoante, resulta -gûábo: t. ú I tr. "comer", ger. gû-ábo; t. suú I tr. "morder", ger. sug $\hat{u}$-ábo; 
f) se a vogal final do tema fôr nasal ou nasalizada pela consoante precedente, o sufixo se nasalizará, tomando a forma -(a)mo: t. nupã I tr. "açoitar", ger. nupã-mo; t. mo-eẽ I tr. "salgar", ger. moeē-mo; t. apyrõ II tr. "chorar alguém", ger. apyrõ-mo; t. kytĩ I tr. "cortar", ger. kytî-ámo; t. mo-ñe-mũ I caus. "fazer pazes", ger mo-ñe-m̂̂-ámo; t. manó I intr. "morrer", ger. manó-mo.

2.4.4. Os seguintes temas formam irregularmente o gerúndio: t. iké I intr. "entrar", ger., iké-ábo ou iké-bo; t. îepeé I intr. "aquecer-se", ger. îepeé-bo, îepeé-ábo, îepeé-gû-ábo ou îpe-gû-ábo; t. aó I tr. "injuriar", ger. aó-ábo ou agû-ábo; t. soó I tr. "convidar", ger. soó-ábo, soó-gû-ábo ou so-gû-ábo; t. sykyîé I intr. "ter mêdo", ger. syky $\hat{\text {-ábo. }}$

\section{Expressão do objeto direto da 1.a e da 2.a pessoas}

2.5.0. A expressão do objeto direto da 3.a pessoa irreflexiva já foi indicada em 2.1.2.; o objeto da 3.a pessoa reflexiva tem expressão especial na voz reflexiva, 4.4. Nesta seção são indicadas as maneiras por que é expresso o objeto da 1.a e da 2.a pessoas.

2.5.1. Quando o sujeito é da 3.a pessoa e o objeto direto é da 1.a ou da 2.a, êste é expresso pelos pronomes da 1.a classe. O sujeito, então, não se exprime pelos pronomes da 2.a e da 3.a classes, mas pode ficar oculto ou ser expresso por substantivo ou demonstrativo. Exs.: xe-nupã "(êle) me bateu" ou "(êles) me bateram"; xe-nupã xe-r-úb-a ou xe-r-úb-a xe-nupã "meu pai me bateu";kunumí nde-r-epíák "o menino te viu"; ore-r-epîák "viu-nos (excl.)", "viram-nos (excl.)"; îande-r-epíák "viu-nos (incl.)"; pe-súb "visitou-vos", "visitaram-vos"; nde-rera-só "levou-te", "levaram-te".

2.5.2. Quando o sujeito é da 1.a pessoa e o objeto da 2.a, são ambos expressos pelos pronomes oro e opo (4.a classe, 0.5.4), antepostos diretamente ao tema. Estes podem dispensar os pronomes sujeitos xe e oré (1.a classe), os quais, porém, em geral são expressos para distinguir a 1.a s. da 1.a p. Exs.: oroepîák ou xe oro-epiák "eu te vi", oré oro-epîák "nós te vimos"; opo-epîak ou xe opo-epîák "eu vos vi", ore opo-epîák "nós vos 
vimos", oro-súb "eu te visitei" (cp. oro--îo-súb "nós (excl.) o vis-i tamos") oro-era-só ou oro-gû-era-só "eu te levei" (cf. 2.1.2.3. c).

2.5.3. Quando o sujeito é da 2a. pessoa e o objeto da 1a. é êste expresso pelos pronomes da 1.a classe xe e oré, enquanto que o sujeito o é pelos pronomes da 5.a classe îpé e pê̂epé, os quais são pospostos ao verbo. Os pronomes sujeitos da 1a. classe nde e peẽ podem ser empregados por ênfase. Exs.: xe-repiák îepé ou nde xe-r-epiák îepé "tu me viste", ore-r-epiák îepé "tu nos viste"; xe-r-epîak peîepé ou peẽ xe-r-epiák peîepó "vós me vistes" ore-r-epíák peîepé "vós nos vistes".

\section{Indicativo II}

2.6.1. Esta forma onomática, que só ocorre na 1.a e na 3a. pessoas, constrói-se da seguinte maneira:

a) aos temas vocálicos acrescenta-se o sufixo $-\hat{u}$ : $t$. só I intr. "ir", ind. II só- $\hat{\imath}$; t. ekó II intr. "estar", ind. II ekó- $\hat{u}$; t. iuká I tr. "matar", ind. II îuká- $\hat{u}$;

b) aos temas consonânticos acrescenta-se o sufixo i-: $t$. sók I tr. "socar", ind. II sók-i; t. úr II intr. "vir", ind. II úr-i; t. sém I intr. "sair", ind. II sém-i;

c) os temas terminados na semivogal -î ficam inalterados: t. káî I intr. "queimar-se", ind. II káî; t. mo-sã̂̀ I caus. "espalhar", ind. II mo-sãi

2.6.2. Se o tema fôr intransitivo, será precedido pelo nome do sujeito ou pelo respectivo pronome da 1.a classe: kûesé paié só-û "ontem o pajé foi"; kûesé i-xó-û "ontem êle foi"; kûesé xe-só-ûu "ontem eu fui"; kûesé îande-só- $\hat{u}$ "ontem nós (incl.) fomos"; kó paîé r-ekó-û "aqui está o pajé; kó s-ekó-̂̂ "aqui está êle"; kó xe-r-ekó-̂̂ "aqui estou".

Conjugação do t. sém I intr. "sair": 1.a s. xe-sém-i, 1.a p. excl. orè-sém-i, 1a. p. incl. îande-sém-i, 3a. c. i-xém-i "saí, saímos, saíu ou saíram".

2.6.3. Se o tema fôr transitivo, será imediatamente precedido pelo nome do objeto ou pelo respectivo pronome da 1.a classe; o sujeito sempre fica separado do verbo pelo objeto. Exs.: kûesé paîé mbaé-asy-bór-a subán-i "ontem o pajé chu- 
pou (subán-i, t. subán I tr. "chupar o doente") o enfêrmo (mbaé-asy-bór-a)"; kûesé paîé i-xubán-i "ontem o pajé o chupou"; kûesé paîé xe-su-bán-i "ontem o pajé me chupou"; kûesé mbaé-asy-bór-a paîé i-xubán-i "ontem o pajé chupou o enfêrmo" (lit. "ontem enfêrmo pajé o-chupou"). Note-se a diferença de construção e de sentido: kûesé xe-r-ayr-a xe-r-aîyr-a r-epíák-i "ontem meu filho viu minha filha" (lit. "ontem meu filho minha filha viu"), kûesé xe-r-ayr-a xe-r-aîyr-a s-epiák-i "ontem minha filha viu meu filho" (lit. "ontem meu filho minha filha o-viu").

\section{Subjuntivo}

2.7.1. O subjuntivo forma-se com o sufixo -eme: $t$. moñáng I tr. "fazer", subj. moñáng-eme.

$\mathrm{Na}$ junção do sufixo -eme aos temas, observa-se o seguinte:

a) se o tema termina em vogal oral, intercala-se $\mathbf{r}$ entre êle e o sufixo: $t$. só I intr. "ir", subj. só-r-eme;

b) se o tema termina em vogal nasal ou nasalizada, intercala-se n entre êle e o sufixo (cf. 0.3.a): t. nupã I tr. "açoitar", subj. nupã-n-eme;

c) se o tema termina em semivogal, cai a vogal inicial do sufixo: t. kaî I intr. "queimar-se", subj. káî-me;

d) se o tema termina em -b ou $-\mathbf{m}$, freqüentemente cai também a vogal inicial do sufixo, o que acarreta a queda da consoante final do tema: t. páb I intr. "acabar-se", subj. pábeme ou pá-me; t. sém I intr. "sair", subj. sém-eme ou sé-me.

2.7.2. Ao sujeito e ao objeto do subjuntivo aplica-se tudo o que foi dito em 2.6.2-3 a propósito do sujeito e do objeto do indicativo II. Exs.: paîé só-r-eme "se o pajé fôr, quando o pajé fôr"; i-xó-r-eme "se êle fôr", xe-só-r-eme "se eu fôr"; paîé r-ekó-r-eme "se o pajé estiver"; s-ekó-r-eme "se êle estiver"; xe-r-ekó-r-eme "se eu estiver"; paîé mbaé-asy-bór-a subán-eme ou mbaé-asy-bór-a paîé i-xubán-eme "se o pajé chupar o enfêrmo".

Conjugação do t. sém I intr. "sair": 1a. s. xe-sé-me, 1a. p. excl. ore-sé-me, 1.a p. incl. îande-sé-me, 2.a s. nde-sé-me, 2.a p. pe-sé-me, 3.a c. i-xé-me "se eu sair", etc. 
Conjugação do t. ekó II intr. "estar": 1.a s. xe-r-ekó-r-eme, 1.a p. excl. ore-r-ekó-r-reme, 1.a p. incl. iande-r-ekó-r-eme, 2.a s. nde-r-ekó-r-eme, 2a. p. pe-r-ekó-r-eme, 3a. c. s-ekó-r-eme "se eu estiver", etc.

\section{SEGUNDA CONJUGAÇAOO}

3.0. Na 2.a conjugação, que compreende os temas nominais no aspecto verbal, só se empregam os pronomes da 1.a classe. Apenas o gerúndio tem formaçāo especial, diferente da 1.a conjugação.

3.1. Indicativo I. Conj. do t. aób I subst. "roupa": 1.a s. xe-aób, 1.a p. excl. ore-aób, 1.a p. incl. îande-aób, 2.a s. ndeaób, 2.a p. pé-aób, 3.a c. i-aób "tenho roupa", "temos roupas", etc.

Conj. do t. osáng II adj. "sofredor": 1.a s. xe-r-osáng, 1.a p. excl. ore-r-osáng, 1a. p. incl. îande-r-osáng, 2a. s. nde-r-osáng, 2a. p. pe-r-osáng, 3a. c. s-osáng "sou sofredor" ou "sofro", "sofremos", etc.

3.2. Permissivo. Conj. do t. aób I subst. "roupa": 1.a s. ta-xe-aób, 1.a p. excl. t-ore-aób, 1.a p. incl. t-îande-aób, 2.a s. ta-nde-aób, 2.a p. ta-pe-aób, 3.a c. t-i-aób "que eu tenha roupa", etc.

3.3. Imperativo. Conj. do t. oryb II adj. "alegre": 2.a s. nde-r-oryb, 2.a p. pe-r-oryb "sê alegre", "sêde alegres", ou "alegra-te", "alegrai-vos".

3.4. Gerúndio. Forma-se o gerúndio da $2 a$. conjugaçāo com o sufixo -amo, diante do qual se intercala $\mathbf{r}$ se o tema terminar em vogal oral, $n$ se o tema terminar em vogal nasal ou nasalizada. Exs.: t. oryb II adj. "alegre", ger oryb-amo; t. katu I adj. "bom", ger. katú-r-amo; t. pari I adj. "coxo", ger. pari-n-amo.

Ao contrário do que se dá nas outras formas, no gerúndio a 3a. c. é reflexiva.

Conj. do t. katú I adj. "bom": 1a. s, xe-katú-r-amo, 1a. p. excl. ore-katú-r-amo, 1a. p. incl. îande-katú-r-amo, 2a. s. ndekatú-r-amo, 2.a p. pe-katú-r-amo, 3.a c. o-katú-r-amo "sendo eu bom", etc. 
3.5. Indicativo II. Conj. do t. osáng II adj. "sofrecior": 1.a s. xe-r-osáng-i, 1.a pl. excl. ore-r-osáng-i, 1.a p. incl. îande-r-osáng-i, 3.a c. s-osáng-i "sou sofredor" ou "sofro", etc.

3.6. Subjuntivo. Conj. do t. katú I adj. "bom": 1.a s. xekatú-r-eme, 1.a p. excl. ore-katú-r-eme, 1.a p. incl. îande-katú-r-eme, 2.a s. nde-katú-r-eme, 2.a p. pe-katú-r-eme, 3.a c. i-katú-r-eme "se eu fôr bom", etc.

\section{Potencial}

3.7 Os temas verbais intransitivos, ou intransitivados pela incorporação do objeto, pertencentes à 1.a conjugação, podem também conjugar-se pela 2.a conjugação, i. é; com os pronomes da 1.a classe, caso em que significam potência, ciência, inclinação ou costume. Exs.: t. ñeéng I intr. "falar", 1 a. conj. (ind. I) a-ñeéng "eu falo", 2.a conj. xe-ñeéng "sei falar, posso falar"; t. kuáb I tr. "saber" + t. mbaé I subst. "coisa" $=$ mbaé-kuáb "saber alguma coisa", 1.a conj. a-mbaé-kuáb "sei alguma coisa", 2.a conj. xe-mbaé-kuáb "sou entendido, costumo saber coisas; $t$. nupã I tr. "açoitar" + t. poró I "gente" == poró-nupã "castigar", 1.a conj. a-poró-nupã "eu castigo", 2.a conj. xe-poró-nupã "costumo castigar".

Na realidade, o potencial é o nome de ação (7. 1. 1.) conjugado no aspecto verbal: t. ñeéng I intr. "falar" (a-ñeéng "eu falo"), n. aç. ñeéng-a "fala" (xe-ñeéng-a "minha fala"), asp. verb. ñeéng "ter fala, poder falar, saber falar" (xe-ñeéng "tenho fala, posso falar, sei falar").

\section{VOZES}

4.1. Causativa. A voz causativa é aquela em que o sujeito faz outrem praticar a ação, em vez de êle mesmo praticá-la. Há, pois, dois agentes: um imediato, que pratica a ação e que é o objeto direto; outro mediato, que faz aquêle praticá-la e que é o sujeito. Forma-se a voz causativa dos temas intransititivos, inclusive os temas nominais (2.a conjugação), com o prefixo mbo- ou mo- (cf. o.3.f): $t$ úr II intr. "vir", caus. mbo-úr fazer vir"; t. ñán I intr. "correr", caus. mo-ñán "fazer correr"; t. páb I intr. "acabar-se", caus. mo-mbáb (cf. 0.3.a) "fazer acabar-se, acabar"; t. só I intr. "ir", caus. mo-ndó (cf. 0.3.a) "fazer 
ir, enviar"; t. aób I subst. "roupa, ter roupa", caus. mo-aób "fazer ter roupa"; t. oryb II adj. "alegre, estar alegre", caus. mooryb ou mb-oryb "alegrar".

Os temas causativos são transitivos da classe I: $t$. mo-ndó I tr. "enviar", 1.a s. ind. a-î-mo-ndó "eu o enviei".

4.2.1. Causativo-comitativa. $\mathrm{Na}$ voz causativo-comitativa o sujeito faz outrem exercer a açāo, praticando-a êle também; portanto o sujeito e o objeto direto praticam a ação conjuntamente, em companhia, sendo ambos agentes imediatos. Formase esta voz também dos temas intransitivos, inclusive os nominais, com o prefixo ero-: t. ñán I intr. "correr". c. -com. eroñán "fazer correr consigo"; t. sém I intr. "sair", c. -com. eno-sém (cf. 0.3.6.), fazer sair consigo, levar para fora, tirar"; t. poraséî I intr. "dançar", c.-com. ero-poraséî "fazer dançar consigo"; t. aób I subst. "roupa, ter roupa", c. -com. ero-aób "fazer com que tenha roupas e tê-las também"; t. oryb II adj. "alegre, estar alegre", c. -com. ero-oryb "alegrar e alegrar-se, fazer com que se alegre consigo".

4.2.2. Os seguintes temas formam irregularmente o causativo-comitativo: t. só I intr. "ir", c. -com. era-só "fazer ir consigo, levar"; t. ekó II intr. "estar", c. -com. er-ekó "fazer estar consigo, ter": t. úr II intr. "vir", c. -com. er-úr "fazer vir consigo, trazer"; t. úb II intr. "estar deitado", c. -com. er-úb "deitar consigo".

4.2.3. Os temas causativo-comitativos são transitivos da classe II; xe-r-ykeyr-a xe-r-eno-sém "meu irmão mais velho me levou para fora"; îande-r-ubixáb-a îande-r-ero-îebyr "nosso chefe trouxe-nos de volta" (t. ero-îebyr "fazer voltat consigo"); kuñã o-s-arõ o-membyr-a s-er-ekó-bo "a mulher cuida (t. arõ II tr.) de seu filho (t. membyr subst.) tendo-o consigo".

Para a conjugação dos temas causativo-comitativos no indicativo I, v. 2.1.2.3.

4.3. Causativo-prepositiva. Na voz causativo-prepositiva o sujeito faz com que alguém pratique a ação sôbre outrem. Há, pois, très sêres interessados no processo verbal: um agente mediato, um agente imediato e um paciente. Forma-se esta voz com o sufixo -ukár acrescentado aos temas transitivos. $O$ agen- 
te mediato é o sujeito, o paciente é o objeto direto, enquanto que o agente imediato é um objeto indireto regido pela preposição supé (dativo). Exs.: t. îuká I tr. "matar", c. -prep. iuká-ukár: a-îuká-ukár îagûar-eté xe-r-ybyr-a supé "fiz com que meu irmão mais moço (xe-r-ybyr-a) matasse uma onça (îagûáreté)"; t. mo-ndó I caus. "fazer ir, enviar", c.-prep. mo-ndó-ukár: a-î-mo-ndó-ukár kó abá xe-r-úb-a supé "fiz com que meu pai enviasse êste homem" (cp. a causativa simples: a-1̂-mo-ndó kó abá "eu mesmo fiz ir êste homem"); t. epîak II tr. "ver", c. -prep. epîák-úkár: e-s-epîák-ukár nde-r-úb-a supé "fazer com que teu pai o veja".

4.4. Reflexiva. A voz reflexiva é aquela em que o sujeito pratica a ação sôbre si mesmo, sendo, simultâneamente, agente e paciente. Forma-se dos temas transitivos com o prefixo îe- ou ñe- (cf. 0.3.b): t. kutúk I tr. "ferir", refl. îe-kutúk "ferir-se"; t. îuká I tr. "matar", refl. îe-îuká "matar-se"; t. nupã I tr. "açoitar", refl. ñe-nupã "açoitar-se"; t. tym I tr. "enterrar", refl. ñe-tym "enterrar-se"; enôî̀ II tr. "chamar", refl. 䜣enôî (cf. 0.3.e).

Os temas reflexivos são intransitivos: t. îe-kutúk I "ferirse", 1. s. ind. I a-1̂e-kutúk "eu me feri".

4.5. Recíproca. Na voz recíproca os sujeitos praticam a ação uns sôbre os outros, mùtuamente. Esta voz formada dos temas transitivos com o prefixo îo- ou ño- (cf. 0.3.b): t. kutúk I tr. "ferir", rec. îo-kutúk "ferirem-se uns aos outros"; t. îuká I tr. "matar", rec. îo-îuká "matarem-se uns aos outros"; t. enõ̂î II tr. "chamar", rec. ño-enõ̂i "chamarem-se uns aos outros".

Os temas reciprocos são intransitivos: $t$. io-kutúk $I$ "ferirem-se uns aos outros", 1.a p. incl. I îa-îo-kutúk "nós nos ferimos uns aos outros".

4.6. Pelo emprêgo conjunto de afixos de diferentes vozes constituem-se formas mistas: t.aíb I adj. "estragado" + caus. mo-aíb "estragar" + refl. ñe-mo-aíb "estragar-se" + caus. mo-ñe-mo-aíb "fazer estragar-se"; $t$. ún II adj. "preto" + caus. mo-ún "tingir de preto" + rec. ño-mo-ún "tingirem-se de preto mùtuamente; t. îuká I tr. "matar + rec. îo-îuká "matarem-se mùtuamente" + caus. mo-îo-îuká "fazer que se matem 
mùtuamente; t. kutúk I tr. "ferir" + refl. îe-kutúk "ferir-se" + c. -prep. îe-kutúk-ukár "fazer com que outrem o fira"; $t$. byk I intr. "chegar-se" + c. -com ero-byk + refl. 1-ero-byk + caus. mo-î-ero-byk "fazer com que se cheguem' etc.

\section{ASPECTOS}

5.1. Verbo plural. Pela reduplicação monossilábica do tema ${ }^{\ominus}$, obtém-se um verbo plural, que significa a realização múltipla do processo, ou sucessiva ou simultâneamente: $t$. mokón I tr. "engolir", pl. mokó-kón "engolir muitas coisas sucessivamente"; t. sók I intr. "quebrar-se", pl. só-sók "quebrarse por muitas partes (simultâneamente ou sucessivamente)"; t. sém I intr. "sair", pl. sé-sém "saírem sucessivamente"; t. pór I intr. "dar um salto", pl. pó-pór "dar (muitos) saltos".

5.2.1. Frequientativo. Pela reduplicação dissilábica do tema ", obtém-se normalmente o verbo freqüentativo, o qual significa que o processo é repetido diversas vêzes: t. mokón I tr. "engolir', freq. mokó-mokón "engolir muitas vêzes"; t. tykyr I intr. "pingar (cair uma gota)", freq. tyky-tykyr "gotejar".

5.2.2. Se o tema fôr monossilábico, a reduplicação atingirá também a sílaba que o preceder imediatamente, de modo a ser sempre dissilábica. Os sufixos verbais, entretanto, não são considerados na reduplicação, mas tão sómente os prefixos: t. syk I intr. "chegar", 1.a s. ind. I a-syk "chego", freq. a-sy-a-syk "chego muitas vêzes"; 2.a s. ind. I ere-syk "tu chegas", freq. ere-sy-re-syk "tu chegas freqüentemente", caus. mondyk "fazer chegar", freq. mo-ndy-mo-ndyk "fazer chegar freqüentemente"; t. só I intr. "ir", 1.a p. excl. ind. I oro-só, freq, oro-só-ro-só; 1a. p. excl. subj. oro-só-r-eme, freq. oro-só-ro-só-r-eme; 1a. s. ger. gûi-xó-bo, freq. gûi-xó-gûi-xó-bo; t. póî I tr. "dar de comer", 1a. s. ind. I a-îo-póî "dou de comer a êle",

9) A reduplicação monossilábica consiste na repetiçăo da biltima solaba do tema; a reduplicação dissilábica consiste na repetição das duas últimas silabas do tema. Em ambos os casos, se a (última) silaba reduplicante (i. é, a ser repetida) termina em consoante ou semivogal, perde êsse fonema final, o qual, entretanto, se conserva na silaba reduplicada. 
freq. a-1̂0-pó-îo-póî; xe-póî "dão-me de comer", freq. xe-pó-xe-póî.

5.2.3. Quando, porém, o fonema final do tema passa a constituir uma só sílaba com a vogal do sufixo, o que se dá no gerúndio (2.4.3.d-e) a reduplicação abrange essa vogal: t. apití I tr. "matar", ger apitî-ábo, freq. apitî-á-pitî-ábo; t. mo-mbeú I caus. "dizer, narrar", ger. mo-mbegû-ábo, freq. mo-mbegû-á-mbegû-ábo.

5.3. Intensivo. $O$ aspecto intensivo, que denota ser o processo desenvolvido com particular intensidade, pode formarse de três maneiras diferentes:

a) por incorporação do tema katú "bem" ao tema verbal: t. pûeráb I intr. "sarar", int. pûerá-katú "sarar bem"; t. potár I tr. "querer", int. potá-katú "desejar muito";

b)por sufixação de-eté: t. kuáb I tr. "saber", int. kuáb-eté "saber muito";

c) por reduplicação dissilábica do tema: t. mo-îegûák I caus, "enfeitar", int. mo-îegûá-î̀gûák "enfeitar muito, enfeitar bem"; t. ekó-tebē II intr. "estar triste", int. ekó-tebē-tebẽ "estar muito triste".

5.4. Perfectivo. Com o sufixo -umûán ou -umán forma-se o perfectivo, que indica que o processo é realizado completamente: a-s-epiák-umûán "eu já o vi"; a-só-umán "eu já fui"; nde-r-úr-eme a-s-epiák-umûá-ne "quando vieres, já o terei visto"; nde-r-úr-eme-mo a-s-epiák-umûá-mo "se tivesses vindo, eu já o teria visto".

5.5. Frustrativo. Com o sufixo -biã, acrescentado às formas do indicativo, faz-se o frustrativo, o qual significa que não se consegue o fim para que é realizado o processo: a-só-biã "fui, mas não consegui nada"; a-ra-só-biã "levei-o debalde"; a-s-aûsú-biã "amo-o, mas não me ama"; a-îuká-biã "mateio-o, mas sem resultado".

5.6. Lusivo. Com os sufixos $-\tilde{1}$, acrescentado aos temas consonânticos, e ñé (às vêzes -teñé), acrecentado aos temas vocálicos, forma-se o lusivo, o qual denota que o processo é realizado sem nenhum propósito especial, mas por pura re- 
creação: a-1̂-moñáng-1̄ "faço-o por me recrear (sem ser obrigado)"; a-s-epîák-ī "vejo-o só por ver (mas não dou importância)"; a-só-ñé "fui sem necessidade"; a-î-meéng-i "dei-o de graça".

5.7. Exclusivo. O exclusivo, que denota ser o processo realizado com exclusividade, faz-se com os sufixos -i ou -î̃te, -ñóte: o-ám-1 "êle esteve em pé sem sair do lugar"; a-ín-î̃ote, "estive sentado sem me mexer"; a-só-ñóte "não fiz nada mais que ir"; e-îkó-ñóte "estejas parado" ("não faças mais que estar"); e-s-epiák-îôte xe-r-ayr-a "não mexas com meu filho" (lit. "não faças mais que olhar meu filho").

5.8. Fictivo. O fictivo, que indica que o sujeito finge realizar o processo, pode formar-se das seguintes maneiras:

a) por reduplicação dissilábica do tema e sufixação de -aúb: a-só-a-só-aúb "finjo que vou"; a-ra-só-ra-só-aúb "finjo que o levo" (contudo, n-a-s-endúb-eym-aúb-i "fiz que não ouvia");

b) pela incorporação do tema moáng "presumir" ou da forma moáng-aúb: a-1̂-mo-ndó-moáng ou a-î-mo-ndó-moáng-aúb "finjo que o mando"; xe-kutú-moáng "fingiu ferir-me".

5.9. Desiderativo. O desiderativo, que exprime o desejo que tem o sujeito de realizar o processo, é obtido de duas maneiras:

a) com o sufixo -aúb reduplicado dissilàbicamente (aúaúb): a-só-aú-aúb "desejo ir", "vou com grande desejo"; a-rasó-aú-aúb "desejo levá-lo"; às vêzes, porém, ocorre o sufixo simples: a-s-epíák-aúb "desejo vê-lo";

b) pela incorporação do tema potár "querer", e esta é a maneira mais comum: a-só-potár "quero ir"; a-s-epîá-potár "quero vê-lo".

5.10. Iterativo. O iterativo, que indica que o processo é repetido uma vez, é formado com o sufixo -beñé ou beñenó: a-só-beñé "torno a ir"; a-é-beñé "torno a dizer".

5.11. Continuativo. Com o sufixo -bé forma-se o continuativo, que indica que o processo continua a ser realizado: o-karú-bé "ainda está comendo"; a-á-mbé (t. ám I intr. "estar em pé") "continuo em pé"; o-îkó-bé "continua estando, vive". 
5.12. Instativo. $O$ instativo, que significa que o processo esteve a ponto de ser realizado, embora não o tenha sido, forma-se com o sufixo -sûér (às vêzes -sûér-ī): a-îuká-suér "estive a ponto de matá-lo, quase o matei"; a-manó-suér "quase morri"; a-ár-i-xuér "estive na iminência de cair".

5.13. Freqüentativo habitual. Com o sufixo -îa ou $\hat{a} a b y$, obtém-se um freqüentativo habitual, que denota o hábito que há em praticar freqüentemente o processo: a-kañém-íá "costumo fugir amiúde", a-só-1̂́a "costumo ir muitas vêzes", xe-poró-nupã-1́aby "costumo açoitar muito ou muitas vêzẹs".

5.14. Consuetivo. O consuetivo, que denota costume em realizar o processo, é formado com o sufixo -amé, a que se pode acrescentar îepí "sempre": a-só-amé ou a-só-amé-îepí "eu costumava ir, eu ia sempre".

5.15. Volitivo. O volitivo, que exprime uma decisão, forma-se com os sufixos -ká, na linguagem dos homens, e -ky, na das mulheres, acrescentados à 1a. s. e p.: a-só-ká "quero jir" (homem), a-só-ky "quero ir (mulher).

Os sufixos -ká e ky podem ser precedidos por -ne e -pe: a-só-ne-ká ou a-só-pe-ká "quero-me ir" (homem), a-só-ne-ky ou a-só-pe-ky "quero-me ir" (mulher); a-îuká-pe-ká a-é "eu disse que hei de matá-lo, deliberei matá-lo".

\section{MODOS}

6.0. Os três modos assinalados nesta seção não se prendem pròpriamente à morfologia do verbo, mas constituem antes processos sintáticos que interessam à expressão verbal, e só por esta razão são incluídos neste ensaio sôbre a morfologia.

6.1. Intencional. O modo intencional, que dènota que o processo é apresentado como uma intenção, e que tem, por isso, um valor de futuro, é formado com a partícula -ne sufixada ao último elemento da oração: a-só-ne "eu tenciono ir, eu irei"; a-só paraná-me-ne "tenciono ir ao mar, irei ao mar"; oro-gû-era-só ore-tá-pe-ne "pretendemos levá-lo a nossa aldeia".

6.2. Condicional. O condicional, que indica ser o processo apresentado como dependente de uma condição, é formado 
com o sufixo -mo, que se acrescenta ao verbo da oração principal, que fica no indicativo, e ao da oração condicional, que fica no subjuntivo: xe-mo-ndó-r-eme-mo a-só-mo "se me mandassem, eu iria"; ore-r-enõî-me-mo oro-1̂úr-y-mo "se nos chamassem, nós viríamos".

6.3.1: Optativo. O optativo, que denota que o processo atribuído ao sujeito da oração é apresentado como um desejo de quem fala, é formado com a partícula temó, colocada depois da primeira palavra da oração, e a interjeição mã, no fim: o-só temó mã! "oxalá êle fôsse!"; aé temó o-só mã! "oxalá aquêle fôsse!"; xe-r-úb-a temó o-só tá-pe mã! "oxalá meu pai fôsse para a aldeia!".

6.3.2. Com a partícula meîmó ou beîmó, em lugar de temó, obtém-se um optativo com valor perfectivo: a-só meîmó mã! "oxalá eu tivesse ido!".

\section{NOMES DEVERBATIVOS}

7.1.1. Nome de ação. O nome de ação é constituído pelo tema verbal no aspecto nominal, o qual se forma com o sufixo -a nos temas consonânticos e é indistinto nos temas vocálicos (0.4.4.): t. kañém I intr. "fugir", n. aç. kañém-a "a fuga, o fugir"; t. sém I intr. "sair", n. aç. sém-a "a saída, o sair"; t. páb I intr. "acabar-se", n. aç. páb-a (forma absoluta mbáb-a) "fim"; t. só I intr. "ir", n. aç. só "a ida, o ir"; t. bebé I intr. "voar", n. aç. bebé "a ação de voar".

7.1.2. Os nomes de ação dos temas transitivos têm sempre o objeto expresso: t. moñáng I tr. "fazer", i-moñáng-a "a ação de fazê-lo"; t. epî́k II tr. "ver", s-epî́ák-a "a ação de vêlo", xe-r-epíák-a "a ação de ver-me", pe-r-epiák-a "a ação de ver-vos"; t. ekár II tr. "procurar", s-ekár-a "a ação de procurálo", ore-r-ekár-a "a ação de procurar-nos (excl.)", xe-r-úb-a r-ekár-a "a ação de procurar meu pai".

7.1.3. Funcionando como substantivos, os nomes de ação conjugam-se com os pronomes da la. classe como possessivos; quando o tema é transitivo e o objeto é expresso por um pronome, podem ocorrer lado a lado dois pronomes da 1a. classe: o que fica imediatamente iunto 70 tema é o obieto da 
ação, o que precede êste é o possuidor (sujeito): t. só I intr. "ir", xe-só "minha ida", i-xó "a ida dêle ou dêles"; t. sém I intr. "sair", iande-sém-a "nossa (incl.) saída", i-xém-a "a saída dêles", abá sém-a "a saída dos índios", pirá sém-a "a saída dos peixes"; t. epîák II tr. "ver", s-epíák-a "a ação de vê-lo", xe-s-epîak-a "minha ação de vê-lo", nde-s-epîák-a "tua ação de vê-lo"; xe-r-epî́a-a "a ação de ver-me", nde-xe-r-epî́ák-a "tua ação de ver-me, a ação de tu me veres", i-xe-r-epíák-a "a ação de êle me ver"; xe-r-úb-a r-epî́k-a "a ação de ver meu pai", nde-xe-r-úb-a r-epiáak-a "tua ação de ver meu pai, a ação de tu veres meu pai".

7.1.4. Como o nome de ação forma um todo com seu objeto e seu possuidor (sujeito), pode funcionar êsse todo como objeto de um verbo transitivo: a-1̂-potá nde-só "eu quero tua ação de ir, i. é, quero que vás"; a-î-potá nde-xe-r-era-só "eu quero tua ação de fazer-me ir contigo, i. é, quero que tu me leves"; a-î-potá nde-xe-r-ayr-a r-epiák-a "eu quero tua ação de ver meu filho, i. é, quero que vejas meu filho".

7.1.5. Na formação dos tempos ${ }^{10}$ dos nomes de ação, deve-se observar o seguinte:

a) o pretérito irrealizado forma-se regularmente: t. eîké II intr. "entrar", pret. irreal. s-eîké-r-á-mbûér-a;

b) o futuro pode formar-se regularmente, mas em geral é formado com o sufixo -aûám: s-eîké-r-ám-a ou s-eîké-aûám-a;

c) o pretérito é formado com o sufixo -agûér: s-ê̂ké-agûér-a.

7.2.1. Nome de agente. $O$ nome de agente forma-se dos temas transitivos e intransitivos, com o sufixo -ár: t. moñáng I tr. "fazer", n. ag. moñáng-ár-a "autor"; $t$ mo-ingé I caus. "introduzir", n. ag. mo-ingé-ár-a "introdutor"; t. só I intr. "ir", n. ag. só-ár-a "o que vai".

7.2.2. Os nomes de agente formam os tempos regularmente: pres. moñáng-ár-a "autor", fut. moñáng-ár-ámঝa "o

10 Embora não apresente o verbo tupi a categoria de tempo, o nome (qualquer substantivo ou tema no aspecto nominal) pode apresentar-se em 4 tempos: a) presente, sem qualquer afixo próprio; b) futuro, com 0 sufixo -ám (-r-ám, -n-ám, -u-ám); c) pretérito, com o sufixo -uér (-p-uér, -mb-uér); d) pretérito irrealizado, com os dois sufixos (-á-mb-uér = -ám + uér). 
que será autor", pret. moñáng-ár-ûér-a "o que foi autor", pret. irreal. moñáng-ár-á-mb-ûér-a "o que devia ter sido autor, mas não o foi".

7.2.3. Na junção do sufixo -ár aos temas, observam-se as seguintes particularidades:

a) se o tema termina em -î precedido por vogal oral, intercala-se $t$ entre êle e o sufixo: t. póî I tr. "dar de comer", n. ag. póî-t-ár-a "o que dá de comer";

b) se o tema termina em -î precedido por vogal nasal, intercala-se nd (cf. 0.3.a) entre êle e o sufixo: t. mo-sãî I caus. "espalhar", n. ag. mo-sãî-nd-ár-a "o que espalha";

c) se o tema termina em vogal, em geral intercala-se $\mathrm{s}$ entre êle e o sufixo, mas também pode ligar-se o sufixo diretamente ao tema: t. aby I tr. "errar", n. ag. aby-s-ár-a ou aby-ár-a "o que erra";

d) quando, nos temas terminados em vogal nasal, não se intercala s, o sufixo, por influxo da vogal nasal que o precede imediatamente, toma a forma -án (cf. 0.3.a): t. pysyrõ I tr. "salvar", n. ag. pysyrõ-s-ár-a ou pysyrõ-án-a "salvador";

e) se o tema termina em -ú ou em -ó não precedidos por consoante, muda-se esta vogal em gĥ: t. kaú I intr. "beber cauim", n. ag. kagĥ́ár-a "bebedor de cauim"; t. ú I tr. "ingerir", n. ag. gî́-ár-a "o que ingere, comedor ou bebedor"; t. angaó I tr. "ameaçar", n. ag. angag $\hat{u}$-ár-a "o que ameaça";

f) se o tema termina em -b, muda-se êste em -p diante do sufixo: t. endúb II tr. "ouvir", n. ag. endúp-ár-a "o que ouve";

g) se o tema termina em -m, muda-se êste em mb diante do sufixo: t. tym I tr. "enterrar", n. ag. tymb-ár-a "enterrador";

h) se o tema termina em -n, muda-se êste em nd diante do sufixo: t. pobán I tr. "fiar", n. ag. pobánd-ár-a "fiandeiro";

i) se o tema termina em -r, perde essa consoante e pode intercalar-se s diante do sufixo: t. mo-mbór I caus. "lançar", n. ag. mo-mbó-ár-a ou mo-mbó-s-ár-a; quando, porém, a vogal que precede o -r é a, não se pode dispensar o s: t. potár I tr. "querer", n. ag. potá-s-ár-a "o que quer"; 
j) no futuro e no pretérito, porém, os temas terminados em -r podem conservar esta consoante: $t$. potár I tr. "querer", n. ag. fut. potár-ár-ám-a "o que quererá", n. ag. pret. potár-ár-ûér-a "o que quis".

7.3.1. Nome de circunstância. Com o sufixo -áb acrescentado aos temas, tanto transitivos como intransitivos, obtém-se o nome de circunstância, que exprime as circunstâncias de lugar, tempo, modo, causa, instrumento, fim: t. moñáng I tr. "fazer", n circ. moñáng-áb-a "o lugar em que se faz, o tempo em que se faz, o modo por que se faz, a causa por que se faz, o instrumento com que se faz, o fim para que se faz".

7.3.2. O pretérito dos nomes de circunstância forma-se regularmente (-b cai e o suf. toma a forma -gûér); o futuro, porém, é irregular: o sufixo mantém a forma - $\imath$ ám após a queda de -b; p. ex.: pres. moñáng-áb-a "lugar onde se faz, etc.", pret. moñáng-á-gûér-a "lugar onde se fêz, etc."; fut. moñángá-ûám-a "lugar onde se fará, etc.".

7.3.3. Na junção do sufixo -áb aos temas, observam-se as mesmas particularidades assinaladas em 7.2.3, exceto as da alínea $d$, e mais as seguintès:

a) quando, nos temas terminados em $-\tilde{\mathbf{1}},-\tilde{\mathbf{o}},-\tilde{\mathbf{u}}$, não se intercala $s$ diante do sufixo, êste toma a forma -ám (cf. 0.3.c): t. apytĩ $I$ tr. "amarrar", n. circ. apytī-s-áb-a ou apytí-ám-a; t. mo-paũ I caus. "fazer intervalos", n. circ. mo-paũ-s-áb-a ou mo-paũ-ám-a;

b) quando, nos temas terminados em -á, -é, -ã, - -ẽ, não se intercala s diante do sufixo, êste perde a vogal inicial: t. îuká I tr. "matar", n. circ. îuká-s-áb-a ou îuká-b-a; t. ekó-bé II intr. (asp. continuativo) "viver", n. circ. ekó-bé-s-áb-a ou ekó-bé-b-a; t. nupã I tr. "açoitar", n. circ. nupã-s-áb-a ou nupã-m-a.

7.3.4. Com os temas nominais, o nome de circunstância tem valor de nome de objeto: $t$. maé-nd ûár I "lembrado, estar lembrado", n. circ. maé-nduá-s-áb-a "coisa lembrada, coisa de que se está lembrado"; $t$. esaráî II "esquecido, estar esquecido", n. circ. esaráî-t-áb-a "coisa esquecida, coisa de que se está esquecido". 
7.3.5. O mesmo se dá com os verbos transitivos com objeto incorporado: $t$. moñáng I tr. "fazer" $+t$. kó I subst. "roça" = kó-moñáng "fazer roça (para alguém)": a-î-kó-moñáng "eu faço roça para êle", xe-kó-moñáng "fazem roça para mim"; n. circ. kó-moñáng-áb-a "roça feita (para alguém)": i-kó-moñáng-áb-a "roça feita para êle", xe-kó-moñáng-áb-a "roça feita para mim".

7.4.1. Nome de objeto. $O$ nome de objeto, que designa $o$ objeto da ação em relação ao agente, forma-se dos temas transitivos, com o prefixo emi- (embi-). Os temas dêstes nomes pertencem à classe II, podendo sua forma absoluta ser formada pela perda de e- inicial ou pela prefixação de t.. Exs. t. ú I tr. "comer", n. obj. embi-ú: 1a. s. xe-r-embi-ú "o que eu como", abs. mbi-ú ou t-embi-ú "o que a gente come"; t. moñáng I tr. "fazer", n. obj. emi-moñáng: $3 .^{a}$ c. s-emi-moñang-a “o que êle faz, a obra dêle", abs. mi-moñáng-a ou t-emi-moñáng-a "o que a gente faz, obra de gente"; $t$. suú I tr. "mastigar", n. obj emi-nduú (cf. 0.3.a): 1a. s. xe-r-emi-nduú "o que eu mastigo, coisa mastigada por mim", abs. mi-nduú ou t-emi-nduú "coisa mastigada por gente"; t. kaú I tr. "fazer mingau", n. obj. emingaú (0.3.a): abs. mi-ngaú "mingau".

7.4.2. Os tempos dos nomes de objeto formam-se regularmente: pres. xe-r-emi-ú "o que eu como, minha comida", fut. xe-r-emi-ú-r-ám-a "o que eu comerei, o que será minha comida", pret. xe-r-emi-ú-p-ûér-a, "o que eu comi, o que foi minha comida", pret. irreal. xe-r-emi-ú-r-á-mb-ûér-a "o que eu devia ter comido, mas não comi".

7.5.1. Nome de paciente. Dos temas verbais transitivos, com o sufixo -pyr, forma-se o nome de paciente, sempre precedido pelo pronome da $3 a$. c. irrefl.; indica o paciente (= objeto) da ação independentemente do agente. Exs.: t. îuká $I$ tr. "matar", n. pac. i-îuká-pyr-a "o que é morto"; t. mo-ndó I caus. "enviar", n. pac. i-mo-ndó-pyr-a "o que é enviado"; t. eé II tr. "ralar", n. pac. s-eé-pyr-a "o que é ralado".

7.5.2. Formam-se os tempos dos nomes de paciente de maneira regular: pres. i-îuká-pyr-a "o que é morto", fut. i-îuká-pyr- ám-a "o que há-de ser morto", pret. i-îuká-pyr-ûér-a "o 
que foi morto", pret. irreal. i-îuká-pyr-á-mb-ûér-a "o que era para ter sido morto, mas não o foi".

7.5.3. Na junção do sufixo -pyr aos temas, verificam-se as seguintes particularidades:

a) se o tema termina em vogal ou ditongo nasal, o sufixo toma a forma -mbyr (cf. 0.3 a): t. arõ II tr. "guardar", n. pac. s-arõ-mbyr-a "o que é guardado"; t. mo-sãî̀ I caus. "espalhar", n. pac. i-mo-sã̂i-mbyr-a "o que é espalhado";

b) se o tema termina em consoante oral (-b, -r, -k), o sufixo é ligado a êste por meio da vogal -y-: t. â̂súb II tr. "amar", n. pac. s-aûsúb-y-pyr-a "o amado"; t. sók I tr. "socar", n. pac. i-xók-y-pyr-a "o que é socado";

c) se o tema termina em consoante nasal ou nasalizada (-m, -n, -ng), o sufixo é ligado a êste pela vogal -y- e toma a forma -mbyr: t. tym I tr. "enterrar", n. pac. tym-y-mbyr-a "o que é enterrado"; t. subán I tr. "chupar", n. pac. i-xubán-y-mbyr-a "o (doente) que é chupado"; t. aáng II tr. "provar", n. pac. s-aáng-y-mbyr-a "o que é provado".

7.6. Nome de agente habitual. Dos temas intransitivos, com o sufixo -bór, forma-se um nome de agente habitual: $t$. kañém I intr. "fugir", n. ag. hab. kañé-mbór-a "fujão, o que costuma fugir" (cp. n. ag. kañémb-ár-a "o que foge, o que fugiu"); t. maraár I adj. "doente, estar doente", n. ag. hab. maraá-bór-a "o doente, o que anda doente" (cp. n. ag. maraá-s-ár-a "o que ficou doente"); t. ambyasy I subst. "fome", n. ag. hab. ambyasy-bór-a "o que anda com fome, o faminto".

7.7.1. Nome relativo. Com o sufixo -baé acrescentado à 3a. c. do indicativo I (nos verbos transitivos com objeto da $3 a$. c.), forma-se um nome relativo, que equivale à oração relativa com sujeito da 3a. c.: t. só I intr. "ir", 3a. c. ind. I o-só, n. rel. o-só-baé "que vai, o que vai"; t. suú I tr. "morder", 3a. c. ind. I o-îxuú, n. rel. o-î-xuú-baé "o que o morde"; t. er-ekó II c.-com. "ter", 3a. c. ind. I o-ĝ̂u-er-ekó, n. rel. o-gû-er-ekó-baé "que o tem, o que o tem": kunumí ybyrá-pár-a o-gû-er-ekó-baé "o menino que tem um arco"; t. îuká I tr. "matar", 3a. c. oîuká, n. rel. o-îuká-baé "que o mata, o que o mata": abá îagûár- 
-eté o-îuká-baé "a pessoa que mata a onça"; t. maraár I adj. "doente", 3a. c. i-maraár, n. rel. i-maraár-y-baé "o que está doente".

7.7.2. Formam-se regularmente os tempos do nome relativo: pres. o-só-baé "(o) que vai", fut. o-só-baé-r-ám-a "(o) que irá", pret. o-só-baé-p-ûér-a "(o) que foi", pret. irreal. o-só-baé-r-á-mb-ûér-a "(o) que devia tèr ido, mas não foi".

7.7.3. Na junção do sufixo -baé aos temas, observa-se o seguinte:

a) se o tema termina em vogal nasal ou nasalizada, nasaliza-se o b do sufixo: t. arõ II tr. "guardar", n. rel. o-s-arõ-mbaé "(o) que o guarda"; t. manó I intr. "morrer", n. rel. o-manó-mbaé "(o) que morre";

b) se o tema termina em consoante, o sufixo é ligado a êle por meio da vogal -y-: t. epiák II tr. "ver", n. rel. o-s-epîák-y-baé "(o) que o vê"; t. moñáng I tr. "fazer", n. rel. o-îmoñáng-y-baé "(o) que o faz";

c) se, porém, a consoante final do tema fôr -b ou -m, mais freqüentemente esta poderá cair diante da consoante inicial do sufixo: t. aûsúb II tr. "amar", n. rel. o-s-aûsúb-y-baé ou o-s-aûsú-baé "(o) que o ama"; t. sém I intr. "sair", n. rel. o-sém-y-baé ou o-sé-mbaé "(o) que sai".

7.8.1. Nome de propensão. Com o sufixo -sûér, acrescentado aos temas intransitivos, forma-se um nome que indica quem tem gôsto ou inclinação em realizar o processo, quem é dado a realizá-lo: t. atá I intr. "andar", atá-sûér-a "indivíduo dado a andar, andejo"; $t$. îruré I intr. "pedir", iururé-sûér-a "individuo que gosta de pedir".

7.8.2. Na junção do sufixo -sûér aos temas, observa-se o seguinte:

a) se o tema termina em vogal nasal, o sufixo toma a forma -ndûér (cf. 0.3.a): t. ñe-moyrõ I refl. "agastar-se", ñemoyrõ-nd ûér-a "pessoa inclinada a agastar-se";

b) se o tema termina em consoante, o sufixo toma a forma -i-xûér: t. ñeéng I intr. "falar", ñeéng-i-xûér-a "falador, palrador"; 
c) se o tema termina na semivogal -î, o tema toma a forma -xûér (cf. 0.3.d): t. poró-póî I intr. (com objeto incorporado) "dar de comer a gente", poró-póî-xuér-a "pessoa inclinada a dar de comer aos outros".

7.8.3. O nome de propensão pode ser empregado no aspecto verbal: xe-ñeéng-i-xûér "tenho inclinação a falar, gosto de falar muito"; xe-ñe-moyrõ-nd ûér "tenho propensão a agastar-me".

\section{VERBOS DITEMATICOS}

8.0.1. Oito verbos apresentam dois temas, um para as formas remáticas, outro para as formas onomáticas. O tema remático tem por característica o elemento $i$, ou prefixado ao tema onomático (úr/îúr), ou alternando com a vogal inicial dêsse (én/ín). Um nono verbo possui os dois temas independentes entre si (eõ/manó). O tema onomático é sempre da classe II, salvo o tema é do verbo é/í "dizer"; neste verbo, aliás, é bastante irregular a distribuição dos dois temas (cf. 8.9).

8.0.2. Com exceção do verbo ẽ̃/manó "morrer", nos demais verbos intransitivos ditemáticos a 1a. s. do gerúndio é formada do tema onomático, e nos verbos transitivos é também dêsse tema que sai todo o gerúndio; a 1a. s. do gerúndio dos intransitivos apresenta o afixo $t$ entre o pronome e o tema (gûi-t-én-a). Nos verbos úr/î́u "vir", úb/îúb "estar deitado" e ár/îár "tomar", a 3a. c. do indicativo I e do permissivo também sai do tema onomático, bem como a 1a. p. excl. do verbo ár/îár.

8.1. ekó/ikó intr. "estar": ind.. I a-îkó etc.; perm. t-a-îkó etc.; imp. e-îkó, pe-îkó; ger. gûi-t-ekó-bo, oro-îkó-bo etc.; ind. II xe-r-ekó- $\hat{u}$ etc.; subj. xe-r-ekó-r-eme, etc., 3a. c. s-ekó-r-eme, abs. t-ekó-r-eme; n. aç. ekó, 3a. c. s-ekó, abs. t-ekó; n. ag. ekó-ár, ekû-ár, 3a. c. s-ekû-ár-a, abs. t-ekû-ár-a; n. cir. ekó-áb, ekû-áb, 3a. c. s-ekû-áb-a, abs. t-ekû-áb-a.

8.2. én/ín intr. "estar sentado": ind. I a-ín etc.; perm. t-a-ín etc.; imp. e-ín, pe-ín; ger. gûi-t-én-a, oro-ín-a etc.; ind. II xe-r-én-i etc., 3a. c. s-én-i ou n-én-i (plural); subj. xe-r-én- 
-eme etc., 3a. c. s-én-eme; n. aç. én, 3a. c. s-én-a, abs. t-én-a; n. circ. énd-áb, 3a. c. s-énd-áb-a, abs. t-énd-áb-a.

8.3. eîké/iké intr. "entrar": ind. I a-îké etc.; perm. t-a-îké etc.; imp. e-îké, pe-îké; ger. gûi-t-ê̂ké-bo ou ghî-ké-bo (por * gûi-îké-bo), oro-îké-bo etc., ou gûi-ké-ábo, oro-îké-ábo etc.; ind. II xe-r-eîké-û etc.; subj. xe-r-eîké-r-eme etc., 3a. c. s-eîké-r-eme, abs. t-eîké-r-eme; n. aç. eîké, 3a. c. s-eîké, abs. t-eîké; n. ag. eîké-ár ou eîké-s-ár, 3a. c. s-eîké-ár-a, abs. t-eîké-ár-a; n. circ. eîké-áb ou eîké-s-áb, 3a. c. s-eîké-s-áb-a, abs. t-eîké-s-áb-a.

8.4. eîtyk/ityk tr. "derrubar, atirar": ind. I a-îtyk etc.; perm. t-a-îtyk etc.; imp. e-îtyk, pe-îtyk; ger. eîtyk-a xe-r-eîtyk-a etc.; ind. II eîtyk-i: xe-r-eîtyk-i etc.; subj. eîtyk-eme: xe-r-eîtyk-eme etc.; n. aç. eîtyk-a, 3a. c. s-eîtyk-a; n. ag. eîtyk-ár, 3a. c. s-eîtyk-ár-a; n. cir. eîtyk-áb, 3a. c. s-eîtyk-áb-a.

8.5. ár/îár tr. "tomar, colhêr": ind. I a-îár, oro-gû-ár, îa-1̂ár, ere-1̂ár, pe-1ár, o-gû-ár; perm. t-a-îár etc.; imp. e-iár, pe-îár; ger. á: xe-r-á etc., 3a. c. t-á; ind. II ár-i: xe-r-ár-i etc., 3a. c. t-ár-i; subj. ár-eme: xe-r-ár-eme etc. 3a. c. t-ár-eme; $n$. aç. ár, 3a. c. t-ár-a; n. ag. á-s-ár, 3a. c. t-á-s-ár-a; n. cir. á-s-áb, 3a. c. t-á-s-áb-a.

8.6. úr/îúr intr. "vir": ind. I a-îúr, oro-îúr, îa-îúr, ere-îúr, pe-1̂úr, o-úr; perm. t-a-îúr, etc.; imp. e-îór ou e-îór-í ou îór-í, pe-îór ou pe-îór-í; ger. gûi-t-ú, oro-îú, îa-îú, e-îú, pe-1̂ú, o-ú; ind. II xe-r-úr-i etc., 3a. c. t-úr-i; subj. xe-r-úr-eme etc., 3a. c. t-úr-eme; n. aç. úr, 3a. c. t-úr-a, abs. t-úr-a; n. circ. ú-s-áb, 3a. c. t-ú-s-áb-a, abs. t-ú-s-áb-a.

8.7. úb/îúb intr. "estar deitado": ind. I a-îúb etc., 3a. c. o-úb; perm. t-a-îúb etc.; imp. e-îúb, pe-îúb; ger. gûi-t-úp-a, oro-îúp-a etc., 3a. c. o-úp-a; ind. II xe-r-úb-i ou xe-r-ú-i etc., 3a. c. t-úb-i ou t-ú-i; subj. xe-r-ú-me etc., 3a. c. t-ú-me; n. aç. úb, 3a. c. t-úb-a, abs. t-úb-a; n. circ. úp-áb, 3a. c. t-úp-áb-a, abs. t-úp-áb-a.

8.8. ẽ̃/manó intr. "morrer": ind. I a-manó etc.; perm. t-a-manó etc.; imp. e-manó, pe-manó; ger. gûi-manó-mo etc.; ind. II xe-r-eõ-û etc.; subj. xe-r-eõ-n-eme, 3a. c. s-eõ-n-eme, 


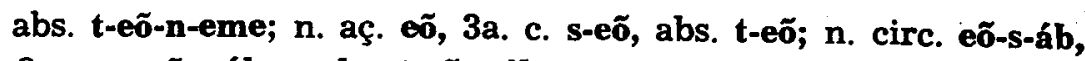
3a. c. s-eõ-s-áb-a, abs. t-eõ-s-áb-a.

8.9. é/í tr. (irregular) "dizer": ind. I a-é, oro-é, îa-é, er-é (por *ere-é), pe-î-é, e-í; perm. t-a-é etc.; imp. er-é, pe-î-é; ger. gûi-î-ábo, oro-î-ábo etc.; ind. II xe-é-û etc., 3a. c. i-é-û; subj. é-r-eme; n. aç. é; n. ag. é-1̂-ár ou î-ár; n. cir. é-s-áb; n. obj. e pac. 1̂-áb "dito".

\section{NEGAÇÃO}

9.1. A negação dos verbos no indicativo é feita com a prefixação de nd- (diante de vogal ou semivogal) ou nda- (diante de consoante) ao pronome sujeito e simultânea sufixação de -i ao tema: a-só "fui", neg. nd-a-só-î "não fui"; oro-só "nós (excl.) fomos", neg. nd-oro-só-1̂; îa-só "nós (incl.) fomos", neg. nd-1̂a-só-î; pe-só "vos fostes", neg. nda-pe-só-1̂; xe-r-osáng "sou paciente", neg. nda-xe-r-osáng-i; nde-r-osáng "és paciente", neg. na-nde-r-osáng-i.

9.2. Quando as formas do indicativo estão nos modos intencional, condicional ou optativo, acrescenta-se ao sufixo -i o sufixo -xoé ou -xó: a-só-ne "tenciono ir, irei", neg. nd-a-só-î-xoé-ne ou nd-a-só-î-xó-ne; o-só-mo "êle iria", neg. nd-o-só-1̂-xoé-mo; o-só temó mã! "oxalá vá êle!", neg. nd-o-só-î-xoé temó mã!

9.3. A negação do imperativo e do permissivo é feita com -umé: e-ra-só "leva-o!", neg. e-ra-só-umé; t-a-ra-só "que eu o leve", neg. t-a-ra-só-umé; ta-s-oryb "alegre-se êle", neg. ta-s-oryb-umé.

9.4. A negação do gerúndio, do indicativo II, do subjuntivo e dos nomes de ação, de objeto e relativo faz-se com o sufixo -eym, o qual é colocado entre o tema e o sufixo modal ou nominal: t. moñáng I tr. "fazer", ger. moñáng-a, neg. moñáng-eym-a; ind. II moñáng-i, neg. moñáng-eym-i; subj. moñáng-eme, neg. moñáng-ey-me; n. aç. moñáng-a, neg. moñáng-eym-a; n. obj. emi-moñáng-a, neg. emi-moñáng-eym-a; n. rel. o-1̂-moñáng-y-baé, neg. o-î-moñáng-ey-mbaé.

9.5. A negação dos nomes de agente, de circunstância e de paciente também se faz com o sufixo -eym, porém interca- 
lado entre os dois sufixos que cada um dêsses nomes comporta: n. ag. moñáng-ár-a, neg. moñáng-ár-eym-a; n. circ. moñáng-áb-a, neg. moñáng-áb-eym-a; n. pac. i-moñáng-y-mbyr-a, neg. i-moñáng-y-mbyr-eym-a.

As vêzes, entretanto, o sufixo negativo ocorre imediatamente junto ao tema: n. ag. moñáng-eymb-ár-a, n. circ. moñáng-eymb-áb-a.

9.6. Na negação do pretérito e do futuro dos nomes de ação, de agente, de circunstância, de paciente e de objeto, o sufixo -eym pode ficar antes ou depois do sufixo temporal: $t$. îká I tr. "matar", n. aç. pret. neg. îuká-agûér-eym-a ou îuká-eym-agûér-a; $n$. aç. fut. neg. îuká-aûám-eym-a ou îuká-eym-aûám-a; n. ag. pret. neg. îuká-s-ár-ûér-eym-a ou îuká-s-árey-mb-ûér-a ou ainda îuká-eymb-ár-ûér-a; $n$. ag. fut. neg. îuká-s-ár-ám-eym-a ou îuká-s-ár-eym-û-ám-a ou ainda îuká-eymb-ár-ám-a; etc.

No pretérito irrealizado, porém, o sufixo negativo não se coloca imediatamente antes dos sufixos temporais: $n$. aç. pret. irreal. neg. îuká-r-á-mb-ûér-eym-a; n. ag. pret. irreal. neg. îuká-s-ár-á-mb-ûér-eym-a ou îuká-eymb-ár-á-mb-ûér-a.

9.7. Negação dupla $=$ afirmação. Com dupla negação constrói-se uma forma afirmativa enfática. No indicativo I, intercala-se o sufixo -eym entre o tema e o sufixo -i da negação comum; no imperativo e no permissivo, intercala-se -eym entre o tema e -umé; as formas que se negam normalmente com -eym, conservando êste, são incapsuladas por nd(a)-. . . -ruã. Exs.: ind. I a-î-potár "eu o quis", neg. nd-a-î-potár-i "não o quis", dupla neg. nd-a-î-potár-eym-i "não deixei de querê-lo"; ind. I o-î-moñáng "êle o fêz", neg. n-o-î-moñáng-i "não o fêz", dupla neg. n-o-î-moñang-eym-i "não deixou de fazê-lo"; imp. e-s-ekár "procura-o!", neg. e-s-ekár-umé "não o procures!", dupla neg. e-s-ekár-eym-umé "não deixes de procurá-lo!"; subj. i-potár-eme "se o quiserem", neg. i-potár-ey-me "se não o quiserem", dupla neg. nd-i-potár-ey-me-ruã "se não deixarem de querê-lo"; ger. i-potá "querendo-o", neg. i-potár-eym-a "não o querendo", dupla neg. n-i-potár-eym-a-ruã "não deixando de querê-lo". 